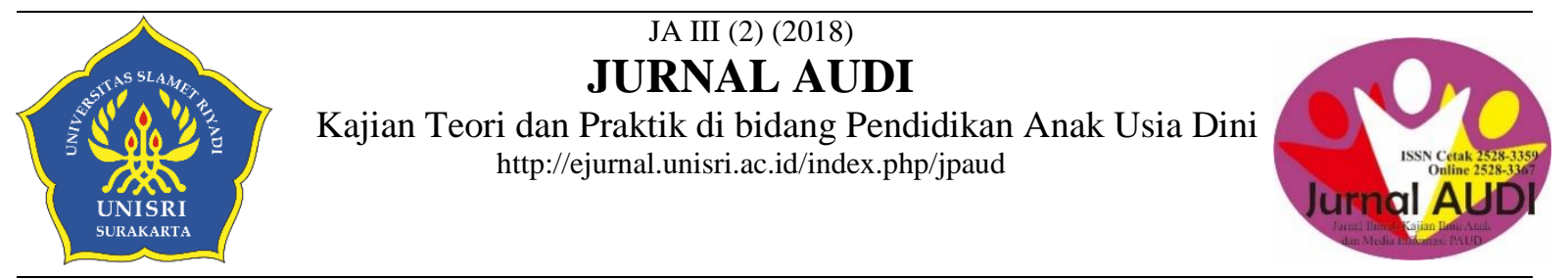

\title{
MENINGKATKAN KEMAMPUAN SAINS MELALUI PERMAINAN WARNA DENGAN MENGGUNAKAN CAT AIR PADA ANAK KELOMPOK B TK NEGERI PEMBINA KABUPATEN TEMANGGUNG
}

\begin{tabular}{|c|c|}
\hline & \\
\hline Info Artikel & \multirow{3}{*}{ 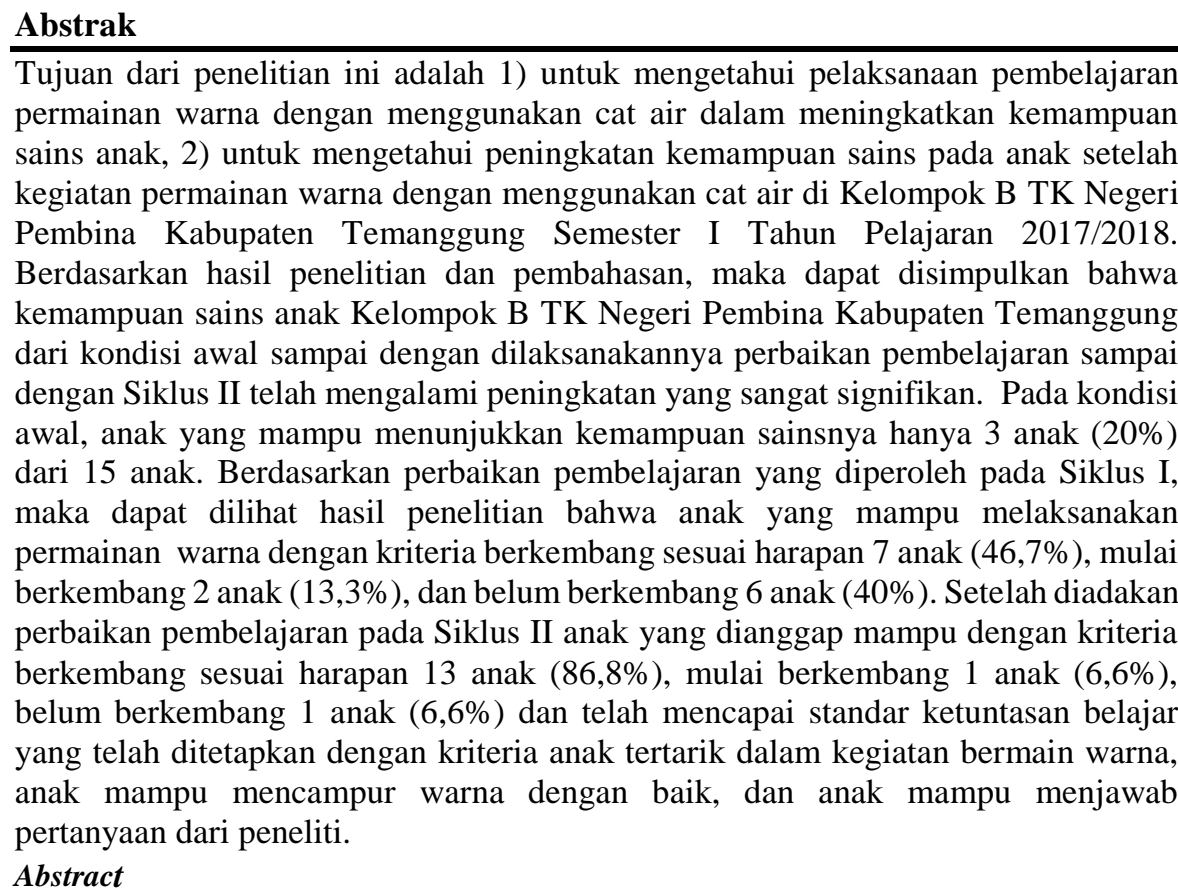 } \\
\hline $\begin{array}{l}\text { Sejarah Artikel: } \\
\text { Diterima Mei } 2018 \\
\text { Disetujui Mei } 2018 \\
\text { Dipublikasikan } \\
\text { Desember } 2018\end{array}$ & \\
\hline & \\
\hline
\end{tabular}

\begin{abstract}
The purpose of this study was 1) to learn the implementation of color games using watercolors to improve children's ability, 2) to learn to improve children's ability to play after the color playing activity using watercolors in Group B of TKanggung District Teachers in Semester I 2017 Academic Year /2018. Based on the results of the research and discussion, it can be concluded that the ability of the Group B children in the TK Pembina Negeri Temanggung Regency from the initial requirements to the implementation of learning improvement up to Cycle II has been significantly increased. In the initial condition, only 3 children (20\%) from 15 children were able to show their scientific abilities. Based on improved learning obtained in Cycle I, it can be seen the results of research on children who are able to work on color games with development proposals according to the expectations of 7 children (46.7\%), start developing 2 children (13.3\%), and have not developed 6 child (40\%). After improving learning in the second cycle, the approved children were able to develop the criteria according to expectations of 13 children (86.8\%), start developing 1 child (6.6\%), have not developed 1 child (6.6\%) and have reached the standard of completeness learning that has been determined by the criteria that children are interested in playing colors, children are able to mix colors well, and children are able to answer questions from researchers.
\end{abstract}

Keywords: Science Skills, Color Games

(C) 2018 FKIP Universitas Slamet Riyadi

Alamat korespondensi: Bebengan, Kertosari, Temanggung

E-mail: burinibukeuje@gmail.com
ISSN 2528-3359 (Print) ISSN2528-3367 (Online) 
Rini Riastuti , Meningkatkan Kemampuan Sains Melalui Permainan Warna Dengan...

\section{PENDAHULUAN}

Kemampuan kognitif diperlukan oleh anak dalam rangka mengembangkan pengetahuan tentang apa yang anak dengar, rasa, raba, maupun cium dengan panca indera. Namun dalam pembelajaran kognitif khususnya pembelajaran sains masih banyak kendala yang terjadi di lapangan, salah satunya adalah kurangnya kreativitas guru dalam membuat media pembelajaran terutama dalam mengenalkan warna pada anak. Untuk itu perlu diciptakan media pembelajaran yang inovatif, kreatif, menarik, ramah lingkungan, dan murah.

Sains penting diperkenalkan kepada anak usia dini karena di era globalisasi ini persaingan sangat ketat sehingga menuntut sumber daya manusia yang berkompeten dalam berbagai bidang, tak terkecuali dalam penguasaan ilmu pengetahuan dan teknologi. Untuk menghasilkan anak yang memiliki penguasaan ilmu pengetahuan dan teknologi yang tinggi dan memadai maka dalam pendidikan anak usia dini diarahkan untuk meningkatkan pembelajaran sains secara lebih menyeluruh tetapi tetap memperhatikan tingkat perkembangan anak.

Anak-anak adalah ilmuwan alami yang dengan aktif mencari informasi mengenai apa yang ada di sekelilingnya, mereka mencoba memahami dunianya melalui pengamatan dan percobaan keingintahuan alami anak-anak, akhirnya menuju belajar. Kegiatan yang cocok untuk mengembangkan pembelajaran sains adalah dengan penerapan keterampilan proses pada tiap tahapannya. Proses sains membekali anak dengan keterampilan memecahkan masalah. Untuk mengembangkan kemampuan sains pada anak adalah dengan melibatkan anak dalam melakukan pengamatan, pengelompokkan, memecahkan penelitian, dan lain sebagainya. Di mana kemampuan sains adalah kemampuan dasar memperoleh pengetahuan sebagai produk dari ilmu pengetahuan alam berupa konsep, hukum-hukum, prinsipprinsip, dan teori. Secara khusus dalam kurikulum TK penekanan tentang pentingnya sains dikembangkan melalui bermacammacam percobaan, mengamati, mengklasifikasikan yang dapat diajarkan kepada anak agar mereka mendapat pengetahuan baru dan pengalaman di bidang sains (Depdiknas : 2004).

Untuk meningkatkan kemampuan sains di Taman Kanak-kanak salah satunya adalah melalui permainan warna dengan menggunakan cat air sebagai salah satu aktivitas bermain untuk anak dan merupakan salah satu indikator sains yang termasuk ke dalam bidang pengembangan kognitif. Melalui kegiatan permaian warna dengan media cat air ini anak dapat belajar dan bereksplorasi serta menemukan pengetahuan mereka tentang warna primer, dan warna lain hasil dari pencampuran warna tersebut. Anak akan diperkenalkan bagaimana warna dibentuk, anak akan mencoba, dan menceritakan apa yang terjadi jika warna dicampur.

Berdasarkan hasil observasi awal yang dilakukan di Kelompok B TK Negeri Kabupaten Temanggung pembelajaran sains masih rendah, cenderung kurang variatif. Hal ini dapat dilihat dari anak yang belum bisa mengenal konsep warna dan menyebutkan hasil pencampuran warna. Selain itu pada saat kegiatan pembelajaran anak hanya mendengarkan penjelasan guru dan melaksanakan tugas dari guru dengan menggunakan media yang terbatas. Pada proses pembelajaran guru kurang memberikan kesempatan kepada anak untuk menggunakan ide dan mengemukakan pendapat anak, kegiatan masih didominasi oleh guru sehingga pembelajaran sains menjadi tidak menyenangkan bagi anak. Hal ini dibuktikan dari 15 anak Kelompok B TK Negeri Kabupaten Temanggung hanya 3 atau 20\% anak yang mampu menunjukkan kemampuan sainsnya terutama tentang permainan warna dan sisanya sebanyak 12 atau $80 \%$ anak belum mampu menunjukkan kemampuan sainsnya dan masih memerlukan bimbingan dari guru.

Untuk itu perlu adanya perbaikan pembelajaran khususnya dalam meningkatkan kemampuan sains anak melalui Penelitian Tindakan Kelas. Berdasarkan permasalahan di atas, peneliti bermaksud mengadakan penelitian tindakan kelas yang berjudul "Meningkatkan Kemampuan Sains Melalui Permainan Warna dengan Menggunakan Cat Air pada Anak Kelompok B TK Negeri 
Rini Riastuti , Meningkatkan Kemampuan Sains Melalui Permainan Warna Dengan...

Pembina Kabupaten Temanggung Semester I Tahun Pelajaran 2017/2018”.

\section{Identifikasi Masalah}

1. Anak-anak belum mengetahui konsep warna.

2. Anak-anak belum mampu menyebutkan hasil penyampuran warna.

3. Media yang digunakan dalam pembelajaran masih terbatas.

4. Kegiatan pembelajaran didominasi oleh guru, sehingga anak kurang mampu mengemukakan pendapatnya.

\section{Batasan Masalah}

Berdasarkan identifikasi masalah yang ada, dalam penelitian ini peneliti membatasi masalah pada kemampuan sains anak yang belum berkembang yaitu anak-anak belum mampu mengenal konsep warna dan menyebutkan hasil penyampuran warna melalui permainan warna menggunakan cat air.

\section{Rumusan Masalah}

Berdasarkan latar belakang masalah di atas maka peneliti merumuskan permasalahan sebagai berikut :

1. "Bagaimana pelaksanaan pembelajaran meningkatkan kemampuan sains melalui permainan warna dengan menggunakan cat air di Kelompok B TK Negeri Pembina Kabupaten Temanggung Semester I Tahun Pelajaran 2017/2018?"

2. "Berapa besar peningkatan kemampuan sains pada anak setelah mengikuti kegiatan permainan warna dengan menggunakan cat air di Kelompok B TK Negeri Pembina Kabupaten Temanggung Semester I Tahun Pelajaran 2017/2018?"

\section{Tujuan Penelitian}

1. Untuk mengetahui pelaksanaan pembelajaran permainan warna dengan menggunakan cat air dalam meningkatkan kemampuan sains di Kelompok B TK Negeri Pembina Kabupaten Temanggung Semester I Tahun Pelajaran 2017/2018.

2. Untuk mengetahui peningkatan kemampuan sains pada anak setelah kegiatan permainan warna dengan menggunakan cat air di Kelompok B TK
Negeri Pembina Kabupaten Temanggung Semester I Tahun Pelajaran 2017/2018.

\section{METODE PENELITIAN}

\section{Tempat Penelitian}

Lokasi penelitian tindakan kelas ini dilakukan di TK Negeri Pembina Kabupaten Temanggung.

\section{Waktu Penelitian}

Penelitian tindakan kelas ini dilaksanakan pada Semester I Tahun Pelajaran 2017/2018, tepatnya pada bulan September sampai dengan bulan Oktober 2017.

\section{Subjek Penelitian}

Subyek penelitian adalah peserta didik Kelompok B TK Negeri Pembina Kabupaten Temanggung yang berjumlah 15 anak, terdiri dari 7 anak laki-laki dan 8 anak perempuan dengan rata-rata usia 5-6 tahun.

\section{Data dan Sumber Data}

Sumber data dibedakan atas data primer dan data sekunder. Sumber data primer adalah objek yang diobservasi langsung di lapangan dan para informan atau pemberi informasi yang diwawancarai. Dalam penelitian ini yang bertindak sebagai sumber data primer adalah anak Kelompok B dan guru TK Negeri Pembina Kabupaten Temanggung, sedangkan data primernya adalah catatan hasil wawancara.

Sumber data sekunder berupa dokumentasi dan arsip-arsip resmi yang dapat mendukung hasil penelitian. Data sekunder ini sangat berharga bagi peneliti guna memahami lebih mendalam tentang permasalahan yang dijadikan objek penelitian. Dalam penelitian ini sumber data sekunder diperoleh dari hasil raport, daftar penilaian, daftar hadir anak, dan dokumen lain yang berhubungan dengan masalah penelitian.

Data yang didapat adalah tentang keadaan TK Negeri Pembina Kabupaten Temanggung dan permasalahan yang terjadi pada anak didik Kelompok B yaitu rendahnya kemampuan sains pada anak.

\section{Teknik dan Alat Pengumpulan Data}


Rini Riastuti , Meningkatkan Kemampuan Sains Melalui Permainan Warna Dengan...

1. Observasi

Alat pengumpulan data yang digunakan yaitu menggunakan lembar observasi untuk mengukur tingkat kemampuan anak dalam pembelajaran sains. Lembar observasi diisi oleh teman sejawat, observer mengisi pedoman observasi yang telah dibuat sesuai dengan aspek-aspek yang diamati.

Pengamatan dalam penelitian ini dilakukan oleh peneliti untuk memperoleh data mengenai kemampuan sains anak Kelompok B Negeri Pembina Kabupaten Temanggung, gambaran kondisi selama proses pembelajaran berlangsung, materi yang disampaikan, metode, dan sumber belajar yang digunakan, mengamati aktivitas anak selama mengikuti kegiatan pembelajaran. Peneliti melakukan pengamatan langsung dengan membawa data observasi yang telah disusun sebelumnya untuk melakukan pengecekan kemudian peristiwa yang diamati dicocokkan dengan data observasi.

2. Wawancara

Wawancara adalah metode pengumpulan data dengan jalan bertanya untuk mendapatkan informasi dengan cara bertanya secara langsung kepada responden. Untuk memperoleh data tentang keadaan TK Negeri Pembina Kabupaten Temanggung, baik kondisi TK maupun anak didiknya, dalam penelitian ini peneliti mengadakan wawancara dengan guru dan kepala sekolah. Dari hasil wawancara ini dapat diketahui respon anak terhadap pembelajaran dan kesulitankesulitan yang dihadapi dalam meningkatkan kemampuan sains anak melalui permainan warna dengan menggunakan cat air.

3. Dokumentasi

Untuk mendapatkan data yang lebih akurat dapat diperoleh dari dokumen yang berupa catatan-catatan, transkrip, buku, surat kabar, majalah, notulen rapat, dan sebagainya. Studi dokumen merupakan pelengkap dari metode observasi dan metode wawancara dalam penelitian.

Dalam penelitian ini metode dokumentasi digunakan untuk mengumpulkan data tentang kemampuan sains anak melalui daftar penilaian.

\section{Analisa Data}

Dari penelitian tindakan kelas ini, data dianalisis Dalam analisis data ini dilakukan perbandingan antara Siklus I dan Siklus II, maka analisis data ini menggunakan deskriptif komparatif, yaitu mendeskripsikan kondisi lapangan yang dapat dilihat pada gambaran obyek penelitian yang telah diperoleh dengan tujuan untuk mengetahui peningkatan kemampuan sains pada anak. Kemudian data tersebut dikomparasikan dengan tinjauan pustaka sebagai tolok ukur penelitian sehingga dapat diambil kesimpulan.

Kemampuan sains anak diukur dengan menggunakan analisis kualitatif yang merupakan bentuk angka dengan rumus sebagai berikut :

$$
P=\stackrel{F}{P} 100 \%
$$

Keterangan :

$\mathrm{P} \quad$ : prosentase yang diharapkan

$\mathrm{F} \quad$ : hasil yang dicapai anak

$\mathrm{N}$ : jumlah anak keseluruhan

\section{Indikator Keberhasilan}

Indikator keberhasilan ini ditandai dengan Untuk menentukan keberhasilan dan keefektifan penelitian, maka dirumuskan indikator yang digunakan sebagai acuan keberhasilan. Adapun acuan keberhasilan penelitian ini adalah adanya peningkatan kemampuan sains pada anak Kelompok B TK Negeri Pembina Kabupaten Temanggung. Dalam penelitian ini keberhasilan ditetapkan minimal $80 \%$.

Tabel 1. Indikator Keberhasilan Anak

\begin{tabular}{|c|c|c|c|c|c|}
\hline \multirow[t]{2}{*}{ No } & \multirow[t]{2}{*}{ Indikator } & \multicolumn{4}{|c|}{ Penilaian } \\
\hline & & BB & MB & BSH & BSB \\
\hline 1 & $\begin{array}{l}\text { Ketertarikan anak } \\
\text { dalam mencampur } \\
\text { warna }\end{array}$ & & & & \\
\hline 2 & $\begin{array}{l}\text { Kemampuan anak } \\
\text { dalam mencampur } \\
\text { warna }\end{array}$ & & & & \\
\hline 3 & $\begin{array}{ll}\text { Kemampuan } & \text { anak } \\
\text { dalam menjawab hasil } \\
\text { permainan mencampur } \\
\text { warna }\end{array}$ & & & & \\
\hline
\end{tabular}


Rini Riastuti , Meningkatkan Kemampuan Sains Melalui Permainan Warna Dengan...

\section{Prosedur Penelitian}

1. Perencanaan Tindakan

Dalam tahap ini peneliti merencanakan penelitian diawali dengan adanya permasalahan bahwa di obyek penelitian rendahnya kemampuan sains anak. Rencana penelitian tindakan kelas merupakan tindakan yang tersusun dan harus memiliki pandangan jauh ke depan, yaitu untuk memperbaiki dan meningkatkan kualitas pembelajaran serta hasil belajar anak, khususnya kemampuan sains anak.

Pelaksanaan penelitian perbaikan pembelajaran yang dilaksanakan di TK Negeri Pembina Kabupaten Temanggung lebih menitikberatkan pada meningkatkan kemampuan sains anak. Pelaksanaannya direncanakan dalam dua siklus untuk mencari alternatif perbaikan kemampuan anak didik.

2. Pelaksanaan Tindakan

Pada tahap ini peneliti memberikan pengarahan kepada peserta didik dalam peningkatan kemampuan sains anak. Bagi yang belum meningkat keefektifan dalam belajar akan diberikan bimbingan khusus.

Dalam pelaksanaan tindakan ini pengamat atau supervisor berperan sebagai tim penilai yang melakukan penilaian terhadap kinerja peneliti dan membantu dalam pelaksanaan perbaikan pembelajaran di TK Negeri Pembina Kabupaten Temanggungtahap yaitu pendahuluan, inti, dan penutup.

3. Pengamatan

Kegiatan pengamatan dilakukan oleh pengamat. Pada kegiatan ini dilakukan perekaman data yang meliputi proses dan hasil dari pelaksanaan kegiatan. Pengamatan dilakukan pada waktu tindakan sedang berjalan. Tujuan dilakukan pengamatan adalah untuk mengumpulkan bukti hasil tindakan yang sudah dilaksanakan agar dapat dievaluasi dan dijadikan landasan bagi pengamat dalam melakukan refleksi.

Untuk mengetahui secara jelas peningkatan kemampuan sains anak di TK Negeri Pembina Kabupaten Temanggung, maka peneliti membuat pedoman observasi terhadap sikap anak yang dilakukan untuk mengetahui secara jelas apakah dengan permainan warna dapat meningkatkan kemampuan sains anak di TK Negeri Pembina Kabupaten Temanggung.

4. Refleksi

Setelah dilakukan observasi sebelum dan sesudah diadakannya upaya meningkatkan kemampuan sains anak melalui permainan warna dengan menggunakan cat air, selanjutnya dilakukan perbandingan hasil observasi sebelum diterapkan upaya tersebut dengan hasil observasi setelah diterapkan upaya meningkatkan kemampuan sains anak melalui permainan warna.

\section{HASIL PENELITIAN DAN PEMBAHASAN}

\section{Kondisi Awal}

Peneliti melakukan pengamatan pertama kali terhadap anak dalam kemampuan kognitif, dari 15 anak Kelompok B TK Negeri Pembina Kabupaten Temanggung hanya 3 anak yang memperhatikan dan aktif dalam pembelajaran dan sisanya sama sekali belum memperhatikan dan pasif dalam mengikuti pembelajaran. Hal ini disebabkan karena kegiatan yang diberikan kurang menarik anak, sehingga anak kurang bersemangat dalam mengikuti pembelajaran. Dari berbagai masalah yang terdapat pada kondisi awal, maka diusahakan untuk mencari pokok permasalahan yang menyebabkan rendahnya kemampuan sains anak. Setelah mengkaji ulang atau mengevaluasi diri terhadap pelaksanaan penelitian serta hasil wawancara dengan beberapa anak dan guru, maka terungkaplah kelemahan-kelemahan yang dialami oleh guru dan anak dalam kegiatan pembelajaran yaitu masih rendahnya kemampuan sains anak.

Dengan ditemukannya kekurangankekurangan tersebut, peneliti merencanakan perbaikan agar anak dapat meningkatkan kemampuan kognitif dengan kegiatan sains melalui permainan warna dengan menggunakan cat air sehingga hasil belajar atau kemampuan sains anak dapat tercapai secara maksimal. 
Rini Riastuti , Meningkatkan Kemampuan Sains Melalui Permainan Warna Dengan...

Dari hasil observasi yang dilakukan pada kondisi awal diperoleh data sebagai berikut :

a. Anak kurang berminat untuk memperhatikan materi pembelajaran yang diajarkan secara monoton dan membosankan.

b. Sebagian besar anak belum melaksanakan tugas yang diberikan, anak asyik bermain sendiri.

Hasil tersebut dapat dilihat pada rangkuman penilaian berikut :

\section{Tabel 1. Kemampuan Sains Anak pada Kondisi Awal}

\begin{tabular}{|l|l|l|l|}
\hline No & Nilai & $\begin{array}{l}\text { Jumlah } \\
\text { Anak }\end{array}$ & Persentasi \\
\hline 1 & BSB & 0 & $0 \%$ \\
\hline 2 & BSH & 3 & $20 \%$ \\
\hline 3 & MB & 2 & $13,3 \%$ \\
\hline 4 & BB & 10 & $66,7 \%$ \\
\hline
\end{tabular}

Keterangan :

BSB : Berkembang Sangat Baik

BSH : Berkembang Sesuai Harapan

MB : Mulai Berkembang

BB : Belum Berkembang

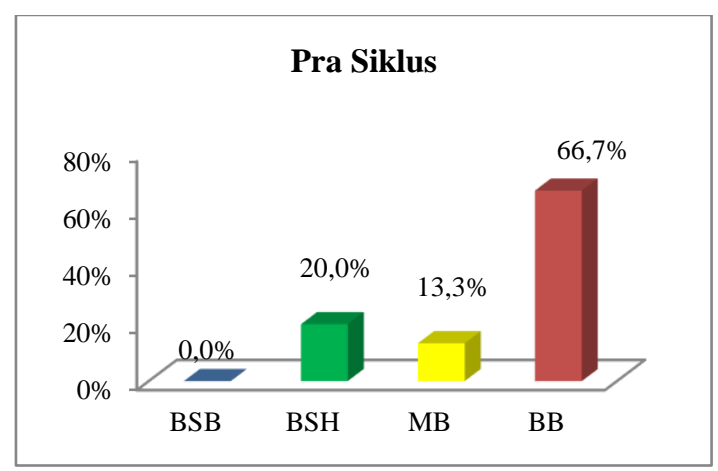

Grafik 1. Kemampuan Sains Anak pada Kondisi Awal

Dari tabel dan grafik di atas dapat diketahui bahwa kemampuan sains anak belum berkembang baik. Hal ini dapat dilihat dari hasil rekapitulasi data kemampuan sains anak Kelompok B yang memperoleh nilai dengan kategori berkembang sesuai harapan hanya sebesar $20 \%$. Perolehan di atas belum mencapai target keberhasilan yang diinginkan yaitu dengan kriteria berkembang sesuai harapan dengan persentase mencapai $80 \%$. Hal ini yang menjadikan landasan peneliti untuk meningkatkan kemampuan sains pada anak Kelompok B TK Negeri Pembina Kabupaten Temanggung melalui permainan warna dengan menggunakan cat air.

\section{Siklus I}

Berdasarkan hasil pengamatan dalam penelitian melalui permainan warna dengan menggunakan cat air pada anak kelompok B di TK Negeri Pembina Kabupaten Temanggung Siklus I, terlihat perkembangan sebagian anak sudah terampil dalam mencampur warna, anak sudah paham dalam melakukan kegiatan yang diberikan, anak sudah mampu melakukan permainan mencampur warna, yaitu dengan mencampur dua warna yang berbeda kemudian akan menghasilkan warna baru, anak sudah banyak yang berhasil melakukan kegiatan yang diberikan sesuai dengan petunjuk. Walaupun belum semua anak berhasil melakukannya secara sempurna.

Berdasarkan hasil data observasi Siklus I dari pertemuan pertama sampai dengan pertemuan ketiga kemampuan sains melalui permainan warna dengan menggunakan cat air pada anak Kelompok B TK Negeri Pembina Kabupaten Temanggung mengalami peningkatan yaitu dari $20 \%$ menjadi $46,7 \%$ dari 15 anak yang diteliti. Hasil persentase tersebut belum dapat dikatakan berhasil karena belum mencapai pada target pencapaian yaitu $80 \%$ anak dengan kriteria penilaian baik.

Tabel 2. Rekapitulasi Kemampuan Sains Anak Siklus I

\begin{tabular}{|l|l|c|l|l|l|}
\hline \multirow{2}{*}{ No } & \multirow{2}{*}{ Pertemuan } & \multicolumn{4}{|c|}{ Nilai Persentasi } \\
\cline { 3 - 6 } & & BSB & BSH & MB & BB \\
\hline 1 & I & $0 \%$ & $20 \%$ & $13,3 \%$ & $66,7 \%$ \\
\hline 2 & II & $0 \%$ & $33, \% 4$ & $13,3 \%$ & $53,3 \%$ \\
\hline 3 & III & $0 \%$ & $46,7 \%$ & $13,3 \%$ & $40 \%$ \\
\hline
\end{tabular}


Rini Riastuti , Meningkatkan Kemampuan Sains Melalui Permainan Warna Dengan...

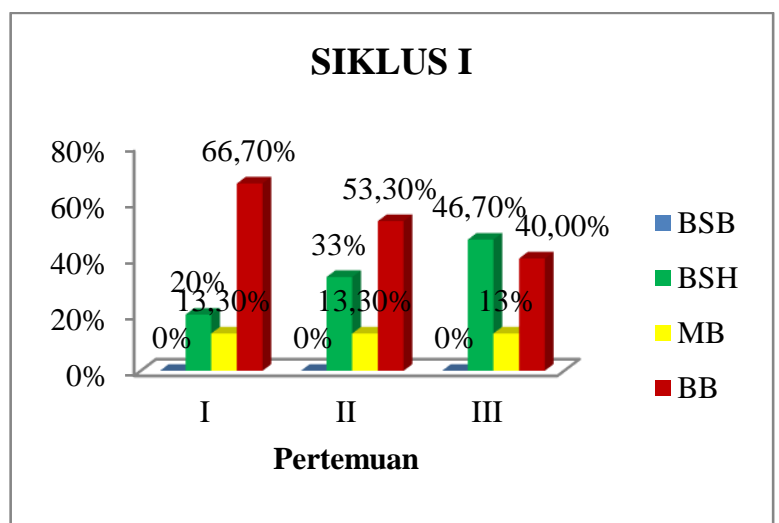

Grafik 2. Kemampuan Sains Anak Siklus I

Dari data tabel dan grafik di atas dapat dilihat bahwa ada peningkatan dari setiap pertemuan. Pada pertemuan pertama anak yang mendapat kriteria berkembang sesuai harapan sebanyak $20 \%$ meningkat menjadi $46,7 \%$ pada pertemuan ketiga. Namun peningkatan tersebut belum sesuai dengan minimal keberhasilan yang ditetapkan yaitu $80 \%$ anak mempunyai kemampuan sains dengan baik.

Peneliti dan guru kelas melakukan diskusi mengenai kegiatan yang telah dilaksanakan dari pertemuan pertama sampai pertemuan ketiga kemudian menjabarkan permasalahan apa saja yang menjadi kendala pada Siklus I sehingga belum dapat mencapai target yang ditetapkan. Permasalahan atau kelemahan yang terjadi pada Siklus I antara lain:

a. Peneliti dalam menyampaikan materi kegiatan terlalu cepat sehingga anak kurang memahami cara mencampur warna dengan benar.

b. Masih ada beberapa anak yang tidak fokus dalam memperhatikan penjelasan guru.

Berdasarkan permasalahan yang muncul pada Siklus I peneliti mencari solusi dari permasalahan tersebut, yaitu :

a. Dalam penyampaian materi, peneliti lebih detail dan tidak terburu-buru sehingga anak akan lebih paham.

b. Memberikan kesempatan kepada anak untuk bertanya.

c. Memberi penjelasan kepada anak dengan cara dan bahasa yang mudah dipahami anak. d. Kegiatan pembelajaran dilaksanakan secara kelompok dan di luar kelas agar suasana lebih menyenangkan.

Kelebihan dari pelaksanaan pembelajaran pada Siklus I adalah :

a. Kegiatan berjalan dengan lancar dan baik sesuai RPPH.

b. Sebagian anak sudah mampu menunjukkan kemampuan sainsnya dibandingkan pada kondisi awal.

\section{Siklus II}

Berdasarkan hasil pengamatan dalam penelitian melalui permainan warna dengan menggunakan cat air pada anak kelompok B di TK Negeri Pembina Kabupaten Temanggung Siklus II, terlihat perkembangan sebagian besar anak sudah terampil dalam mencampur warna, anak sudah paham dalam melakukan kegiatan yang diberikan, anak sudah mampu melakukan permainan mencampur warna, yaitu dengan mencampur dua atau tiga warna yang berbeda kemudian akan menghasilkan warna baru, anak sudah banyak yang berhasil melakukan kegiatan yang diberikan sesuai dengan petunjuk.

Berdasarkan hasil data observasi Siklus II dari pertemuan pertama sampai dengan pertemuan ketiga kemampuan sains melalui permainan warna dengan menggunakan cat air pada anak Kelompok B TK Negeri Pembina Kabupaten Temanggung mengalami peningkatan yaitu dari $60 \%$ menjadi 86,8\% dari 15 anak yang diteliti. Hasil persentase tersebut dapat dikatakan berhasil karena sudah mencapai target pencapaian yaitu $80 \%$ anak dengan kriteria penilaian baik.

Berdasarkan data-data yang diperoleh selama kegiatan perbaikan pembelajaran dari kondisi awal sampai dengan Siklus II mengalami peningkatan yang sangat signifikan, pada siklus II kemampuan yang dicapai sudah mencapai $86,8 \%$ yang dapat dikatakan baik dan mencapai indikator keberhasilan yang telah ditetapkan yaitu $80 \%$ anak mampu meningkatkan kemampuan sainsnya melalui permainan warna dengan menggunakan cat warna. Pada Siklus II terlihat perkembangan anak sebagai berikut :

a. Anak sangat antusisas melaksanakan kegiatan yang diberikan. 
Rini Riastuti , Meningkatkan Kemampuan Sains Melalui Permainan Warna Dengan...

b. Anak dapat melakukan kegiatan dan menceritakan tentang hasil karya yang dibuatnya.

Peningkatan kemampuan sains pada anak Kelompok B dapat dilihat melalui persentase yang diperoleh pada Siklus II dari pertemuan pertama sampai pertemuan ketiga, sebagai berikut :

Tabel 3. Rekapitulasi Kemampuan Sains Anak Siklus II

\begin{tabular}{|l|l|l|l|l|l|}
\hline N & \multirow{2}{*}{$\begin{array}{l}\text { Pertemua } \\
\mathrm{n}\end{array}$} & \multicolumn{4}{|l|}{ Nilai Persentasi } \\
\cline { 3 - 6 } & $\begin{array}{l}\text { BS } \\
\mathrm{B}\end{array}$ & BSH & MB & BB \\
\hline 1 & I & $0 \%$ & $60 \%$ & $\begin{array}{l}13,3 \\
\%\end{array}$ & $\begin{array}{l}26,7 \\
\%\end{array}$ \\
\hline 2 & II & $0 \%$ & $\begin{array}{l}66,7 \\
\%\end{array}$ & $20 \%$ & $\begin{array}{l}13,3 \\
\%\end{array}$ \\
\hline 3 & III & $0 \%$ & $\begin{array}{l}86,6 \\
\%\end{array}$ & $6,6 \%$ & $6,6 \%$ \\
\hline
\end{tabular}

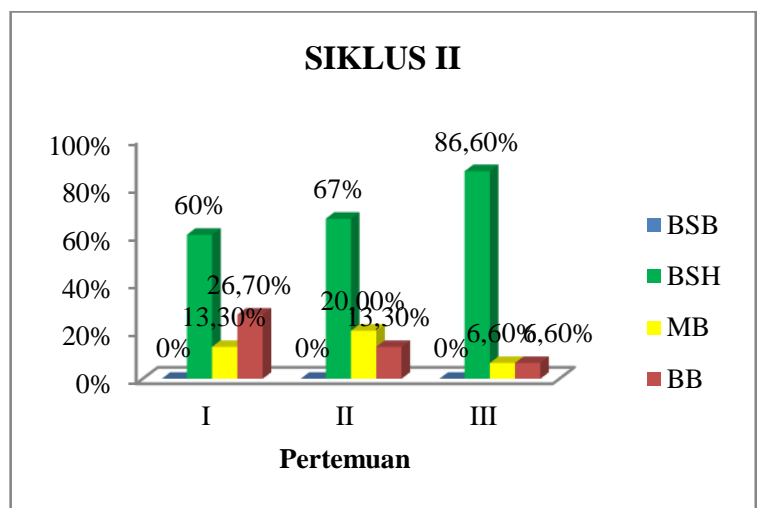

Grafik 3. Kemampuan Sains Anak Siklus II

\section{Pembahasan Hasil Penelitian}

Berdasarkan perbaikan pembelajaran pada kondisi awal sampai dengan Siklus II tentang peningkatan kemampuan sains melalui permainan warna dengan menggunakan cat air pada anak kelompok B TK Negeri Pembina Kabupaten Temanggung, dapat diperoleh data sebagai berikut :

\section{Kondisi Awal}

Berdasarkan data yang diperoleh pada kondisi awal, bahwa kemampuan sains anak sebelum diadakan perbaikan pembelajaran dengan kegiatan permainan warna sangat rendah yaitu anak yang mendapat nilai dengan kriteria berkembang sesuai harapan sebanyak 3 anak (20\%), mulai berkembang 2 anak $(13,3 \%)$, dan belum berkembang 10 anak
(66,7\%). Pada kondisi awal ini, guru kurang memanfaatkan media pembelajaran dan metode yang digunakan masih monoton, guru hanya memberikan penjelasan yang membuat pembelajaran kurang menarik perhatian anak.

\section{Siklus I}

Berdasarkan hasil perbaikan pembelajaran pada siklus I, peneliti memberikan pembelajaran dengan permainan pencampuran warna. Peneliti memberikan penjelasan dan mendemontrasikan cara mencampur warna, yaitu mencampurkan dua warna yang berbeda yang akan menghasilkan warna baru. Pembelajaran Siklus I dari pertemuan pertama hingga pertemuan ketiga, dapat dilihat hasil penelitian bahwa anak yang mendapat nilai dengan kriteria berkembang sesuai harapan 7 anak $(46,7 \%)$, mulai berkembang 2 anak (13,3\%), dan belum berkembang 6 anak (40\%). Maka dapat disimpulkan bahwa pada Siklus I pelaksanaan perbaikan pembelajaran belum optimal sehingga perlu dilanjutkan pada Siklus II karena belum mencapai indikator keberhasilan yang telah ditetapkan yaitu sebesar $80 \%$ anak mampu meningkatkan kemampuan sainsnya.

\section{Siklus II}

Pada pelaksanaan perbaikan pembelajaran pada Siklus II peneliti lebih mengoptimalkan lagi kegiatan yang akan dilaksanakan, kegiatan pembelajaran dilaksanakan di luar kelas agar anak tidak bosan, dan anak dibagi dalam beberapa kelompok, peneliti memberikan reward kepada anak yang sudah mampu melaksanakan tugas yang diberikan agar anak lebih bersemangat dan memberikan motivasi kepada anak yang belum mampu melaksanakan tugas dengan baik.

Penilaian yang diperoleh pada Siklus II adalah anak yang mendapat nilai dengan kriteria berkembang sesuai harapan 13 anak (86,8\%), mulai berkembang 1 anak $(6,6 \%)$, dan belum berkembang 1 anak $(6,6 \%)$. 
Rini Riastuti , Meningkatkan Kemampuan Sains Melalui Permainan Warna Dengan...

Tabel 4. Ketuntasan Hasil Belajar Anak

\begin{tabular}{|c|c|c|c|c|c|c|c|}
\hline \multirow[t]{2}{*}{$\begin{array}{l}\mathrm{N} \\
\mathrm{o}\end{array}$} & \multirow{2}{*}{$\begin{array}{l}\text { Ketunt } \\
\text { asan } \\
\text { Hasil } \\
\text { Belajar }\end{array}$} & \multicolumn{2}{|c|}{$\begin{array}{l}\text { Pra } \\
\text { Siklus }\end{array}$} & \multicolumn{2}{|c|}{ Siklus I } & \multicolumn{2}{|c|}{ Siklus II } \\
\hline & & $\begin{array}{l}\mathbf{J} \\
\mathrm{m} \\
\mathrm{l}\end{array}$ & $\%$ & $\begin{array}{l}\mathbf{J} \\
\mathrm{m} \\
\mathrm{l}\end{array}$ & $\%$ & $\begin{array}{l}\mathbf{J} \\
\mathrm{m} \\
1\end{array}$ & $\%$ \\
\hline 1 & BSB & 0 & $0 \%$ & 0 & $0 \%$ & 0 & $0 \%$ \\
\hline 2 & $\mathrm{BSH}$ & 3 & $\begin{array}{l}20 \\
\%\end{array}$ & 7 & $\begin{array}{l}46, \\
7 \%\end{array}$ & $\begin{array}{l}1 \\
3\end{array}$ & $\begin{array}{l}86, \\
8 \%\end{array}$ \\
\hline 3 & MB & 2 & $\begin{array}{l}13, \\
3 \%\end{array}$ & 2 & $\begin{array}{l}13, \\
3 \%\end{array}$ & 1 & $\begin{array}{l}6,6 \\
\%\end{array}$ \\
\hline 4 & $\mathrm{BB}$ & $\begin{array}{l}1 \\
0\end{array}$ & $\begin{array}{l}66, \\
7 \%\end{array}$ & 6 & $\begin{array}{l}40 \\
\%\end{array}$ & 1 & $\begin{array}{l}6,6 \\
\%\end{array}$ \\
\hline
\end{tabular}

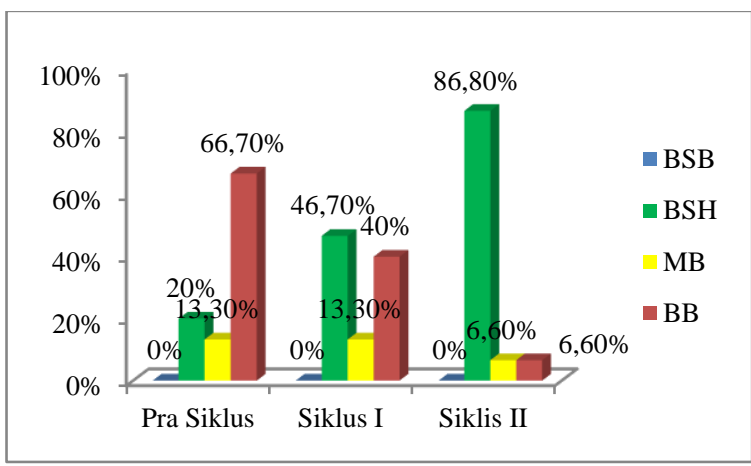

Grafik 4. Ketuntasan Hasil Belajar Anak

Dari hasil penelitian di atas dapat terlihat bahwa untuk meningkatkan kemampuan sains anak dapat dilakukan dengan permainan warna menggunakan cat air. Dengan permainan warna menggunakan cat air anak memiliki kemampuan mengamati perubahan-perubahan yang terjadi di sekitarnya, anak dapat melakukan percobaanpercobaan sederhana, anak dapat mengkomunikasikan sesuatu sebagai hasil dari pengamatan yang dilakukannya, anak dapat meningkatkan kreativitas dan inovasi dalam bidang ilmu pengetahuan alam sehingga akan dapat memecahkan masalah yang dihadapinya.

\section{KESIMPULAN DAN SARAN Kesimpulan}

Berdasarkan hasil penelitian, maka dapat diambil kesimpulan bahwa kemampuan sains anak Kelompok B TK Negeri Pembina Kabupaten Temanggung dari kondisi awal sampai dengan dilaksanakannya perbaikan pembelajaran sampai dengan Siklus II telah mengalami peningkatan yang sangat signifikan. Pada kondisi awal, anak yang mampu menunjukkan kemampuan sainsnya hanya 3 anak (20\%) dari 15 anak. Berdasarkan perbaikan pembelajaran yang diperoleh pada Siklus I, maka dapat dilihat hasil penelitian bahwa anak yang mampu melaksanakan permainan warna dengan kriteria berkembang sesuai harapan 7 anak $(46,7 \%)$, mulai berkembang 2 anak (13,3\%), dan belum berkembang 6 anak (40\%). Setelah diadakan perbaikan pembelajaran pada Siklus II anak yang dianggap mampu dengan kriteria berkembang sesuai harapan 13 anak $(86,8 \%)$, mulai berkembang 1 anak $(6,6 \%)$, belum berkembang 1 anak $(6,6 \%)$ dan telah mencapai standar ketuntasan belajar yang telah ditetapkan, yaitu dengan adanya ketertarikan anak dalam mencampur warna, kemampuan anak dalam mencampur warna, dan anak mampu menjawab hasil permainan mencampur warna yang telah dilakukan

Ketuntasan hasil belajar anak yang mampu melaksanakan permainan warna dengan kriteria berkembang sesuai harapan dari kondisi awal sebesar $20 \%$ ke Siklus I mengalami kenaikan sebesar 26,7\%, dari Siklus I ke Siklus II mengalami kenaikan sebesar $40 \%$, sehingga dari kondisi awal ke Siklus II mengalami kenaikan sebesar $66,7 \%$.

Berdasarkan hasil penelitian yang telah dilaksanakan terbukti bahwa melalui permainan warna dengan menggunakan cat air dapat meningkatkan kemampuan sains anak pada Kelompok B TK Negeri Pembina Kabupaten Temanggung Semester I Tahun Pelajaran 2017/2018, hal ini dapat dibuktikan dengan adanya ketertarikan anak dalam mencampur warna, kemampuan anak dalam mencampur warna, dan anak mampu menjawab hasil permainan mencampur warna yang telah dilakukan.

\section{Saran}

Agar sekolah dapat menyediakan sarana dan prasarana pembelajaran yang diperlukan dalam mengembangkan kemampuan anak, khususnya kemampuan sains. Dengan menerapkan metode, media, strategi yang tepat dalam pembelajaran sains pada anak usia dini diharapkan kemampuan sains dapat berkembang secara optimal.

Guru diharapkan dapat meningkatkan proses pembelajaran terutama kegiatan 
Rini Riastuti , Meningkatkan Kemampuan Sains Melalui Permainan Warna Dengan...

bermain yang bervariatif dan menyenangkan sehingga anak-anak tidak bosan dan tidak terbebani mengikuti pembelajaran.

\section{DAFTAR PUSTAKA}

Amien. 2008. Mengajarkan Ilmu Pengetahuan Alam (IPA) dengan menggunakan Metode "Discovery " dan "Inquiry ". Jakarta: Depdikbud Dikti PPLPTK

Arikunto, Suharsimi. 2007. Prosedur Penelitian Suatu Pendekatan Praktek. Jakarta : Rineka Cipta.

Darma Prawira, Sulasmi. 1989. Warna sebagai Salah Satu Unsur Seni dan Desain. Jakarta: Departemen Pendidikan dan Kebudayaan

Departemen Pendidikan Nasional. 2002. Acuan Menu Pembelajaran pada Pendidikan Anak Usia Dini (Menu Pembelajaran Generik). Jakarta : Depdiknas Direktorat Pendidikan Anak Usia Dini.

Desmita. 2007. Psikologi Perkembangan. Bandung: PT Remaja Rosda Karya

Ebdi Sanyoto, Sadjiman, Drs. 2005. DasarDasar Tata Rupa dan Desain. Yogyakarta: Arti Bumi Intaran

Fajrin, Shofa. 2014. Peningkatan Kemampuan Kognitif Mengenal Warna dengan Media Bahan Alam pada Anak. Skripsi.

Gagne, Robert. 1976. Essential of Learning for Instruction. New York. Alih Bahasa Agus Gerrad

I.L.Pasaribu dan B. Simanjuntak. 2003 Proses Belajar Mengajar. Bandung : Tarsito

Kunandar. 2009. Langkah Mudah Penelitian Tindakan Kelas Sebagai Pengembangan Profesi Guru. Jakarta: Rajawali Pers.

Lexy J Moleong. 2004. Metode Penelitian Kualitatif. Bandung: Remaja Rosda Karya

Menteri Pendidikan. 2003. Undang-Undang Republik Indonesia No 20. Tahun 2003 tentang Sistem Pendidikan Nasional (SISDIKNAS). Bandung: Citra Umbara.

Murniati, Desri. 2014. Meningkatkan Kemampuan Sains Anak Melalui Metode Eksperimen pada Kelompok B di PAUD Haqiqi Kota Bengkulu. Skripsi.

Nasution. 2003. Metode Research. Jakarta : PT. Bumi Aksara

Nugraha, Ali. 2007. Dasar-dasar Matematika dan Sains. Jakarta : Universitas Terbuka.

Nugraha, Ali. 2008. Pengembangan Pembelajaran Sains pada Anak Usia Dini. Bandung: JILSI Foundation.

Permendiknas. 2009. Standar Pendidikan Anak Usia Dini. Jakarta : Permendiknas.

Saepudin. 2012. Pembelajaraan Sains pada Program Pendidikan Anak Usia Dini. http://www.forumpaudntb.org/index.ph p?option $=$ com_content $\&$ view $=$ article $\&$ id=83:pembelajaran-sains-padaprogrampaud\&catid=101:beranda

Sardiman, A. M. 2006. Interaksi dan Motivasi Belajar Mengajar. Jakarta: PT. Raja Grafindo Persada.

Semiawan, Conny R. 2002. Belajar dan Pembelajaran dalam Taraf Usia Dini (Pendidikan Prasekolah dan Sekolah Dasar). Jakarta: PT Prehallindo.

Solehuddin, M. 2003. Konsep Dasar Pendidikan Pra Sekolah. Bandung: Fakultas Ilmu Pendidikan UPI

Sugiyono. 2009. Metode Penelitian Pendidikan : Pendekatan Kuantitatif, Kualitatif dan R\&D. Bandung : Alfabeta.

Sujiono, Yuliani Nurani. 2004. Metode Pengembangan Kognitif. Jakarta : Universitas Terbuka.

Sukardi, Dewa Ketut. 2003. Manajemen Bimbingan dan Konseling di Sekolah. Bandung: Alfabeta.

Sukmadinata, Nana Syaodih. 2006. Metode Penelitian Pendidikan. Bandung: PT.Remaja Rosdakarya

Tim Penyusun Kamus Besar Bahasa Indonesia. 1989. Kamus Besar Bahasa Indonesia. Jakarta.

Trianto. 2010. Mengembangkan Model Pembelajaran Tematik, Jakarta: PT Prestasi. 